\title{
A representação dos povos de Gog e Magog no mapa de Hereford e a percepção da alteridade na baixa Idade Média
}

\author{
Paulo Roberto de Núñez Soares ${ }^{2}$
}

O mapa-múndi de Hereford, maior mapa que sobreviveu à Idade Média, apresenta uma síntese do conhecimento medieval sobre o mundo. Entre seus diversos conjuntos iconográficos, a representação dos povos distantes ocupa espaço relevante. A análise da representação dos povos de Gog e Magog, que têm a descrição mais completa, nos ajuda a compreender a percepção medieval do Outro.

Palavras-chave: Alteridade, cartografia, medieval.

The representation of the people of Gog and Magog on the map of Hereford and the perception of otherness in the Middle Ages

The world map of Hereford, the largest map that survived the Middle Ages, presents a synthesis of the medieval knowledge about the world. Among his many iconographic sets, the representation of distant people has a relevance space. The analysis of the representation of the people of Gog and Magog, who have the most complete description, helps us understand the medieval perception of the Other.

Keywords: Otherness, cartography, Medieval.

1 Artigo recebido em 10.3.2012 e aprovado para publicação em 3.5.2012.

2 Doutor em História pela Universidade de Brasília (2005). Analista Legislativo da Câmara dos Deputados.E-mail: paronuso@gmail.com 
La représentation des peuples de Gog et Magog sur la carte de Hereford et la perception de l'altérité dans le Moyen Age

La carte du monde de Hereford, la plus grande carte qui a survécu le Moyen Age, présente une synthèse des connaissances médiéval sur le monde. Parmi ses nombreux ensembles iconographiques, la représentation des peuples lointains prend une place considérable. Lanalyse de la représentation des peuples de Gog et Magog, qui ont une description plus complète, nous aide à comprendre la perception médiévale de l'Autre.

Mots-clés: Altérité, cartographie, médiéval.

O mapa-múndi de Hereford foi confeccionado no final do século XIII, na Inglaterra. É o maior mapa que sobreviveu à Idade Média, possuindo 1,59 m de altura por aproximadamente $1,40 \mathrm{~m}$ de largura. Não se encontra inserido em nenhum manuscrito nem é acompanhado por nenhum códice. Composto por uma única peça, foi preparado para exposição permanente na catedral da cidade de Hereford, no sudoeste inglês. Seu autor (ou responsável) foi Ricardo de Haldingham, clérigo da catedral de Hereford. Produzido com a pele inteira de um novilho e fixado em um tríptico de carvalho, que ao mesmo tempo o guardava e lhe dava suporte para exposição, congrega informações geográficas, históricas, religiosas, zoológicas e etnográficas, como uma grande enciclopédia ou Summa. É tentador definir o mapa como uma Summa, afinal, produto do mesmo tipo de pensamento que as catedrais góticas e a escolástica. Representa o ápice da família dos mapas ecumênicos. ${ }^{3}$

Na Idade Média Ocidental, não havia uma palavra, em latim ou vernáculo, que se possa traduzir exatamente como mapa. Objetos como o de Hereford eram muitas vezes chamados de descriptio, forma ou imago - às vezes, a palavra mappa era empregada, mas apenas para indicar que a descriptio fora feita sobre um pedaço de tecido (mappa). Do mesmo modo, não havia uma área de saber equivalente à geografia, ou mesmo à cartografia. $\mathrm{O}$ conhecimento sobre as partes do mundo era dado pela geometria, que o mensurava e descrevia. Ricardo não pode ser tratado como um cartógrafo, nem o objeto que produziu, como um mapa, em sentidos modernos. O uso e as funções da forma mundi de Hereford

3 Os mapas-múndi medievais podem ser divididos em três famílias: os hemisféricos, os intermediários e os ecumênicos. Ver ANDREWS, Michel. The study and classification of medieval mappamundi. Archeaologica, v. LXXV, p. 61-76, 1925-1926. 
ultrapassam a mera descrição do espaço ou a indicação temática de determinado assunto. A descriptio representava o que havia na Criação, refletindo-a como um speculum ou expressando-a como o sudário. ${ }^{4}$ Do mesmo modo, Ricardo era um intelectual, um clérigo conhecedor do latim e leitor de livros plenos de autoridade, como o Physiologus ${ }^{5}$ e as Etimologias de Isidoro de Sevilha. Não era um técnico responsável pela confecção de objetos de uso cotidiano. Era um geômetra, pois conhecedor dos limites da Terra.

Objeto ainda relativamente pouco pesquisado, em especial no Brasil, o mapa de Hereford e a cartografia medieval permitem ampliar a compreensão da específica visão de mundo do período e o entendimento sobre as específicas categorias por ela utilizadas para interpretar o funcionamento do Cosmos e o lugar do homem na Criação. O mapa, produzido no interior da Igreja e amparado em autoridades tanto clássicas quanto eclesiásticas, assume o duplo papel de descrição legítima e legitimadora de uma peculiar imagem do mundo e, ao apresentar toda a Criação em uma única página, a função de reafirmar os eixos principais dessa imagem, inevitavelmente marcada pelas peculiaridades do cristianismo medieval.

\section{$A$ alteridade em Hereford}

A ciência etnográfica constitui uma área do conhecimento nascida entre o final do século XIX e o início do XX. Representa uma perspectiva moderna e depende, em sua origem, do desenvolvimento de características da sociedade ocidental formadas no processo de contato com o Outro a partir de experiências coloniais e na superação destas. Para a Idade Média, não se pode falar em etnografia como uma disciplina autônoma. O olhar medieval sobre o Outro em nada se compara às perspectivas da atual ciência etnográfica. Todavia, uma reflexão sobre a alteridade e uma definição de seu lugar foi elaborada sem uma teorização específica, mas na prática da descrição.

Apesar de relativamente econômico na representação de alteridades, o mapa de Hereford expressa em seu programa iconográfico as especificidades daquela

4 RIBEIRO, Maria Eurydice de Barros. O sentido da história: tempo e espaço na cartografia medieval, séculos XI-XIII. Tempo, v. 7, n. 14, p. 14, jan./jun. 2003.

5 Tratado sobre os animais e seres da natureza, atribuído a Plínio, o Velho. Fonte de diversos bestiários. 
descrição. É claro que as diferentes regiões da Europa modulavam o estilo geral da percepção da alteridade de maneiras peculiares. Os contatos com outras civilizações sempre foram muito mais fortes e continuados nas Penínsulas Itálica e Ibérica que na ilha britânica - e, quando estes ocorriam, as dinâmicas que os envolviam e os grupos que se relacionavam eram diferentes. Ao Sul, as civilizações urbanas e mercantis de Bizâncio e dos árabes eram mais presentes que no Norte, mais facilmente assolado por grupos tribais ou de centralização estatal relativamente recente.

Buscar, pois, um "olhar medieval sobre o Outro" que ignore as especificidades regionais e dos grupos culturais - certamente os letrados tinhan uma perspectiva diferente dos iletrados - é tarefa fadada ao erro ou à simplificação. O mapa-múndi de Hereford, por suas condições de produção, espelha uma perspectiva eminentemente letrada e clerical. Utiliza-se do vasto referencial clássico e das tradições já bem assimiladas ao cristianismo, conforme a organização que lhes era atribuída pelo saber erudito da época. Porém, como se prestava a uso pedagógico, possui a peculiaridade de refletir, mesmo indiretamente, a perspectiva de seus receptores. Sua exposição pública implica a possibilidade de leitura mais ampla. Torna-se, portanto, instrumento que permite vislumbrar o construto geral em que se inseria o olhar medieval sobre o Outro.

Há, no mapa, 23 referências a povos distantes, e 11 têm figuras acompanhadas de legenda. Nessa seleção, o critério utilizado foi a não apresentação de características portentosas ou monstruosas. Os monstros e portentos eram criaturas de humanidade questionável, senão claramente inumanos - posição defendida por Agostinho de Hipona, que só considerava humanos os descendentes de Adão e Eva, o que não seria o caso das criaturas portentosas, como centauros, esfinges, panotios ${ }^{6}$ e cinocéfalos, ${ }^{7}$ dentre outros, apesar de sua aparência lembrar a de seres humanos. Assim, os portentos expostos no mapa devem ser considerados como integrantes do mundo natural ou, dito de outra forma, já que a oposição natureza/humanidade é uma construção moderna, como integrantes de um mundo não humano. Quando há, a descrição dos diversos povos costuma ser pobre, em geral apresentando apenas um elemento distintivo. Uma das maiores legendas

6 Assemelham-se a pessoas, mas possuem orelhas tão grandes que podem cobrir todo o corpo, como se fossem uma capa.

7 Têm um corpo humano, mas cabeça de cachorro. 
possui nove palavras e diz: "Solin dicit . eones insula qui ihabitat . omnis marinar auiu viuut" [Solino diz: os habitantes das ilhas Eones vivem de aves marinhas]. Encontram-se a nordeste, próximos à ilha dos Ipopodes, homens com pés de cavalos, e as iconografias mais próximas são uma cadeia de montanhas e um rio, sem relação direta com o texto. Uma das menores possui três palavras e diz simplesmente: "Hircani . hic habitant" [Os hircani habitam aqui]. Está perto do rio Oxus, também a nordeste. Umas poucas são ainda mais lacônicas, como a que diz apenas Hungari, na fronteira leste da Europa.

A etnografia de Hereford não se preocupa com a história dos povos apresentados, com uma única exceção, tampouco se preocupa em retratar seu cotidiano. Trata-os unidimensionalmente, indicando apenas um elemento distintivo e marcante, como em um exercício mnemônico. ${ }^{8} \mathrm{O}$ olhar medieval sobre o Outro, espelhado em Hereford, indica uma percepção redutora da alteridade - apenas constata-se sua existência e destaca-se uma única característica constitutiva.

No século XIII, a experiência direta com o mundo ainda importava menos que o peso da autoridade. A descrição do Outro em Hereford vergava sob esse peso. Mesmo sendo um mapa do século XIII, as referências a muçulmanos virtualmente inexistem. ${ }^{9}$ Os povos retratados não o são por fruto da experiência, mas por obediência à autoridade, já que indicados em textos utilizados como referência pelo geômetra. A percepção da alteridade não deve ser buscada, pois, no contato, mas na tipologia em que se inserem, ou melhor, na tipologia disponivel ao Outro. É como se o mapa de Hereford fosse um produto intelectual conservador, cuja produção interna a uma instituição dominante e bem-inserida no sistema o fizesse espelhar sentidos tradicionais e úteis a sua manutenção. Por outro lado, como um produto artístico, buscava a perfeição, e, como produto religioso, a eternidade, não se prendendo a questões menores, como a representação da época circundante.

As fontes etnográficas de Hereford foram as mesmas que lhe forneceram seus elementos geográficos, zoológicos e monstruosos. As descrições dos povos distantes eram cópias de trechos de Isidoro de Sevilha, Solino, Martiano Capella e, principalmente, da Expositio Mappe Mundi, por sua vez ela mesma uma colagem

8 Característica de um sistema de comunicação fortemente marcado pela oralidade.

9 Exceto por uma referência indireta, na representação do Bezerro de Ouro com o nome de Mahu - Maomé. 
de trechos daquelas fontes. Mais que tratados sobre os povos do orbis, as fontes do mapa acabavam por fornecer curiosidades frouxamente conexas. As figuras etnográficas de Hereford acabaram por espelhar suas fontes, pois não apresentam nenhuma conexão explícita entre si, mas ganham alguma coerência como representações da diversidade do mundo e elementos de um inventário. Nenhuma delas possui referência temporal explícita, o que permite vê-las como representações de povos contemporâneos ao geômetra e seu público. Apesar de determinadas figuras no mapa incorporarem o tempo, tornando-o uma representação não só das três dimensões do espaço, mas também da dimensão temporal, as representações da alteridade inserem-se exclusivamente no presente. Mesmo a representação dos povos de Gog e Magog, que se articula com o passado, quando Alexandre os enclausurou, e com o futuro, quando servirão ao Anticristo, os apresenta em um estado atual, presos atrás de altos muros. Aliás, a única iconografia que os caracteriza é o largo muro que os retém em uma relativamente pequena península na Scythia (Figura 1). Poder-se-ia considerar que não há iconografia para esses povos, uma vez que só se veem um muro e, atrás dele, um longo verbete. Todavia, a iconografia de Hereford caracteriza-se por seu caráter ideográfico - apresenta um elemento de uso consagrado que reflete o sentido do ente representado.

Figura 1. Muro que prende os povos de Gog e Magog - Mapa de Hereford..$^{10}$

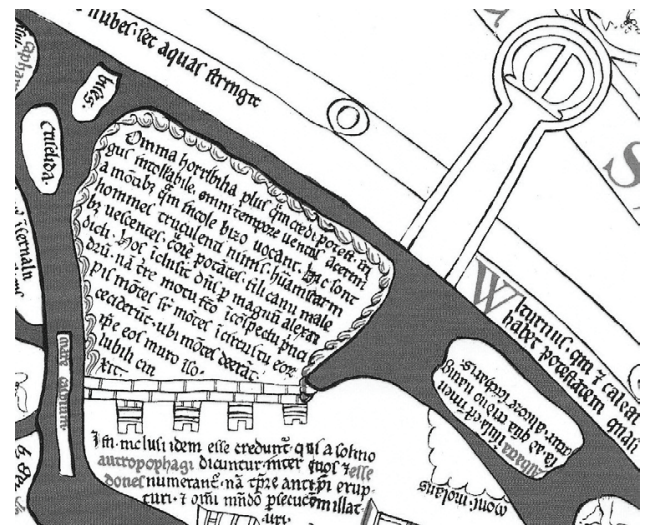

De longe, o texto descritivo desses povos é o maior dos verbetes de etnicidade, sendo uma das maiores legendas do todo o mapa. Há, na verdade, dois verbetes,

10 Hereford mappamundi. Cópia fac-símile por Konrad Miller, 1896, editada por Wychwood Editions, distribuída por Hereford Map Centre, Church Street, 24/25, Hereford, HR1 2LR, Inglaterra. 
um por trás dos muros e outro fora, com informações que se complementam. A importância dada aos povos de Gog e Magog deve-se, sem dúvida, ao teor escatológico do mapa, dominado pela representação do Julgamento Final e pela distribuição das letras da palavra MORS [morte] em seus quatro cantos - vê-se um grande $\mathrm{M}$, no alto, à esquerda da prisão e fora do mapa propriamente dito. A ausência de figuras é compensada largamente pela riqueza da descrição dos terríveis hábitos dos servidores do Anticristo. ${ }^{11}$ Todavia, essa riqueza apresenta um problema. Se o mapa fazia parte da decoração de uma catedral e devia atuar como suporte catequético, um grande texto em latim tem seu alcance reduzido em virtude do desconhecimento dessa língua pelo vulgo no século XIII. A figura do muro seria tão forte e autoexplicativa para quem a visse que prescindiria do texto? Acreditamos que sim, mas não seria forte sozinha. Como o muro é a característica distintiva desses povos, basta sua figuração para a garantia do recurso mnemônico necessário, mas a conexão entre significante e significado necessita da prédica. Em um de seus níveis de leitura, o mapa é uma mensagem emitida pela Igreja para um receptor leigo. Para a boa decodificação da mensagem, o receptor necessita de chaves fornecidas obrigatoriamente pelo emissor. A boa interpretação do significado do muro depende da transmissão de uma chave oral, de uma prédica em que essa característica distintiva seja apresentada e para a qual a representação pictórica sirva como mais um suporte para a memória.

Nesse sentido, o largo texto por trás dos muros pode ser interpretado como um recurso de autoridade. As letras e palavras remetem a um texto, um documento escrito que, em uma sociedade de oralidade mista, ${ }^{12}$ pode apresentar-se como um depositário quase místico de saber; afinal, extrair de um pedaço de pergaminho com manchas negras palavras que podem ser ouvidas é uma arte muito especial. Ademais, o texto em que se baseava a legenda era a própria Bíblia - ela mesma imbuída dessa aura que envolve a eternidade da palavra escrita, que refletia a eternidade da palavra de Deus. O mistério do sentido da escrita pode fornecer à representação dos povos do Anticristo o caráter misterioso e a reverência necessária a descrição tão importante.

11 O grande texto da legenda é retirado de passagens do Gênesis (10: 1-5), Ezequiel (38) e Revelações (20: 7-10). Cf. KLINE, Maps of medieval thought: the Hereford paradigm. Woodbridge, Suffolk: Boydell Press, 2001. p. 185. Note-se que o texto bíblico refere-se aos povos de Gog e Magog, mas o mapa não lhes dá esse nome.

12 Zumthor, Paul. A letra e a voz. São Paulo: Cia. das Letras, 1993. 
O maior dos dois verbetes ligados ao muro informa os horrores que esses povos ainda cometem, mesmo aprisionados, e volta ao passado para descrever seu aprisionamento realizado por Alexandre. A segunda legenda, que completa a primeira e trata do futuro, quando esses povos servirão ao Anticristo, encontra-se fora dos muros, talvez em um exercício metafórico, em que a prisão e posterior libertação seja indicada pela posição dos verbetes em relação à muralha.

A Península em que se encontram presos ocupa uma posição extrema no mapa, projetando-se para dentro do Mar Oceano e quase rente aos limites da carta. Não me parece ser coincidência que o ' $M$ ' da palavra $M O R S$ se localize vizinho a essa Península, com a haste que o sustenta traçando uma linha reta com a cadeia de montanhas que complementa o isolamento realizado pela muralha. Esses povos serão os principais responsáveis pela mortandade que precede o Juízo.

Além da letra ' $M$ ', outra figura próxima que torna a região um espaço definitivamente malévolo é o fluvius infernalis, representado logo abaixo da Península, próximo à cabeça bovina. ${ }^{13} \mathrm{O}$ rio deságua no Mare Caspium, que o conhecimento geográfico medieval baseado em Isidoro acreditava ser conectado ao Oceano. ${ }^{14}$ A legenda, apenas parcialmente visível na figura acima, informa que esse rio vem dos infernos, pois encontra o mar com suas águas fervendo. Seu curso nasce nas montanhas Umbrosi (sombrias), onde se diz que se abre o Gehenna. Essas informações encontram-se na margem esquerda do rio; na margem direita é informado seu nome, fluvius achen, provavelmente uma corruptela ou abreviatura de Acherontus [Aqueronte].

A conexão desses povos, enclausurados atrás de uma grande muralha, de uma cadeia de montanhas e pelo mar, com a mortandade que precederá o fim dos tempos e com o Anticristo, é sustentada por outros dois componentes do mapa, ambos fortemente caracterizados pela escrita, a saber, a letra ' $M$ ' e a legenda do rio achen - note-se que a imagem do rio não denuncia sua origem infernal. $\mathrm{O}$ recurso a uma legitimação escrita reforça o caráter catequético da passagem, pois dependente da intervenção de um letrado/clérigo para se fazer compreender. A escrita também pode ser entendida como uma metáfora da Palavra (escrita) da Bíblia.

13 Essa cabeça é parte da representação de um animal que lembra o Minotauro. Não há conexão direta entre essa criatura e o ambiente que a cerca.

14 Cf. WESTREM, The Hereford map. Turnhout: Brepols, 2001. p. 101-103. 


\section{A legenda interna aos muros diz:}

Omnia horribilia plus $q^{a} m$ credi potest . frigus intollabile omni tempore ventus acerim a môtibs q" $m$ incole bizo vocant. Hic sont homines truculenti nimis. humanis carnibus vescentes . cruorẽ potãtes . fili caim maledicti . Hos ĩclusit dñs [Dominus] per magnũ alexandrũ . nam terre motu facto in conspectu principis mõtes sr" mõtes in circuito eor ceciderũt . ubi mõtes deerãt ipse eos muro ĩsolubili cinxit [Todos os horrores, além do que se pode crer. Frio intolerável. Todo o tempo um vento gélido vem dos montes que chamam "Bizo". Aqui há homens demasiadamente truculentos. Alimentam-se de carne humana. Bebem sangue. Filhos malditos de Caim. Deus os enclausurou por meio do grande Alexandre. De fato, a Terra se moveu no ilustre combate em presença do príncipe, e montes sobre montes caíram ao redor deles, impedindo-lhes a fuga. Onde não havia montanhas, ele (Alexandre) construiu um muro indestrutível].

A passagem informa elementos da história desses povos, das características geográficas e ambientais do lugar em que vivem, alguns de seus hábitos e mesmo uma palavra de sua língua - Bizo. ${ }^{15}$ É o registro etnográfico mais completo do mapa. O único que apresenta mais de um aspecto da vida do povo representado, mas, mesmo assim, ainda os apresenta unidimensionalmente. Todos e cada um dos indivíduos desses povos são maléficos, todos são "filhos malditos de Caim". A primeira coisa que se diz é que aquele lugar e aquelas pessoas representam todos os horrores "além do que se pode crer", e todo o resto apenas confirma essa sentença.

Entre o ambiente circundante e os horrores que nele se passam estabeleceu-se uma relação. Não que os medievais acreditassem sociologicamente que o homem é um fruto de seu meio, mas homens extremos compartilhavam com seu ambiente o caráter liminar de sua existência. A vida humana, como os medievais a concebiam, não podia ser compartilhada por esses seres. Sua região deveria ser tão dura como seus corações. Para provocarem dor e sofrimento na escala em que provocariam, os filhos de Caim deveriam compartilhar desse sofrimento. O caráter repulsivo de sua vida refletia-se no ambiente igualmente repulsivo em que viviam. Como estavam bem ao Norte, em uma posição extremada, o clima era extremo. $\mathrm{O}$ frio era intolerável. Apenas seres mais bestas que humanos o suportariam.

Aqueles homens deveriam ser os mais embrutecidos do orbis. Sua missão era promover a pior das guerras. Mas não bastava a agressividade do clima e das relações sociais. Eles deveriam desrespeitar tudo o que era humano. Deveriam

15 WESTREM, S. D. Op. cit., p. 68, informa que a palavra é, na verdade, um termo francês para o vento Norte. 
realizar os mais horrendos e violentos atos. E o que poderia ser mais agressivo do que comer a carne de outros homens e beber seu sangue? Afinal, esse era seu destino, tornar-se o martelo da humanidade. Eram humanos, mas representavam o anti-humano, por isso devoravam nossa carne. A um animal é permitido comer carne humana, afinal, não têm razão e sua selvageria os justifica, mas outros homens devorarem seus irmãos, isso é demoníaco. Não à toa que são os filhos de Caim. São assassinos de seus irmãos.

A indicação de uma origem genealógica é um elemento importante na representação da alteridade na Idade Média. Os livros de história sempre apresentam a genealogia das nações. O mapa de Hereford define-se como uma descrição do mundo feita a partir do livro Sete livros de história, de Paulo Orósio. ${ }^{16}$ Neste, os povos são sempre apresentados a partir de uma genealogia. Orósio não foi o criador dessa tradição, vinda da profunda Antiguidade, mas foi um dos principais veículos dela para a Idade Média. O padrão se repete em outros livros de história, como na Historia Brittonum, de Nennius, escrita no século IX, mas com acréscimos que chegam até o século XIII, em que, no capítulo 10, os bretões são apresentados como descendentes de gregos e romanos, pois seu povo descende

do lado da mãe de Lavínia, a filha de Latino, rei da Itália, e da raça de Silvano, o filho de Ínaco, o filho de Dárdano; que era filho de Saturno, rei dos gregos, e que, possuindo uma parte da Ásia, construiu a cidade de Troia. Dárdano era o pai de Troilo, que era o filho de Príamo e Hécuba; Anquistes era o pai de Eneias, que era o pai de Ascânio e Sílvio; e este Sílvio era o filho de Eneias e Lavínia, a filha do Rei da Itália. ${ }^{17}$

Sílvio, chamado de Póstumo, pois nasceu depois da morte de seu pai, era o pai dos bretões. Um gens era, pois, como uma família, com uma cabeça e um ancestral fundador.

O ancestral é importante não só para indicar um ponto de origem, mas principalmente para fornecer ao povo um caráter. Como os romanos, que em deter-

16 Na parte de baixo do mapa está inscrito Descriptio orosii de ornesta mundi . sicut interius ostenditur. Há certa controvérsia sobre a tradução dessa frase, em especial da palavra ornesta, mas consideramos que a melhor tradução é "Descrição de Orósio da beleza do mundo, como exibido por inteiro". O cartógrafo refere-se aos Sete livros de história contra os pagãos, escritos por Paulo Orósio no século V a pedido de Santo Agostinho. O primeiro livro, capítulo II, descreve as partes do orbis e deve ter servido como um roteiro para o geômetra definir os limites do mundo que pretendia exibir por inteiro.

17 Cf. tradução de Adriana Zierer. In: COSTA, Ricardo da (Org.). Testemunhos da história: documentos de história antiga e medieval. Vitória: Edufes, 2002. p. 221. 
minada fase de sua história buscaram relacionar-se com um passado glorioso por meio de sua inserção em uma linhagem que vinha de Eneias, os medievais identificavam o caráter dos povos com o de seus ancestrais. Se um gens buscava reforçar sua dignidade, sua ancestralidade era buscada em figuras mitológicas que representassem valores elevados. Cada povo descende de uma figura-chave. As gentes eram, na verdade, como grandes grupos tribais, com um ancestral (mítico?) fundador, talvez seu totem, e certamente a corporificação de sua dignidade. No caso dos povos de Gog e Magog, como se buscava reduzir-lhes a dignidade, seus antepassados só poderiam ser indignos. E quem melhor do que Caim para gerar uma descendência maldita?

Gens tão desgraçado precisava ser contido, afinal, apenas no momento certo deveria aparecer no palco da história para desempenhar seu papel de coadjuvante no terrível drama do Juízo Final. Deus, portanto, teve de utilizar um de Seus instrumentos para contê-los, e apenas um grande homem poderia desempenhar essa função: Alexandre, que, apesar de pagão, tinha estatura suficiente para bem desempenhar esse papel. Na tradição medieval, Alexandre fora um dos maiores monarcas, padrão e modelo para todos os outros.

Orósio, uma das principais fontes do mapa de Hereford, no terceiro livro de suas Histórias, ${ }^{18}$ narra os eventos marcantes da vida desse príncipe, mas nada diz sobre sua luta contra os futuros servidores do Anticristo, e o caracteriza como um líder sanguinário. Porém, no vasto tempo entre o século V e o XIII, Alexandre tornou-se signo de virtude e bom governo. Para a cavalaria, tornou-se um de seus modelos ideais. Ignorando o Alexandre de Orósio, o geômetra de Hereford o adota como instrumento divino e "ilustre príncipe". A conexão entre as conquistas de Alexandre e o enclausuramento dos povos de Gog e Magog teria se dado por meio de interpolações entre versões em vernáculo de sua lenda e o livro de Revelações, realizadas ao redor do século VII por Pseudo-Methodius. ${ }^{19}$ Outra forte influência foi a Cosmographia, de Aethicus Ister, ${ }^{20}$ esta última uma fonte

18 O livro se concentra em suas conquistas desde a vitória sobre Dario até sua morte, envenenado por um escravo, na Babilônia. Descreve algumas batalhas e desfila uma longa lista de territórios conquistados.

19 Cf. ANDERSON, Alexander's gate: Gog and Magog, and the inclosed nations. Cambridge, 1932 apud KLINE, Naomi R. Op. cit., p. 184-186.

20 Id. Ibid. 
direta utilizada na confecção do mapa. Dadas as semelhanças, a Cosmographia deve ter fornecido a base do texto da legenda do mapa. ${ }^{21}$

Alexandre venceu esses inimigos com o auxílio divino. As montanhas desabaram para criar uma barreira natural, apenas completada pelo enorme muro construído pelo Macedônio. Pode-se levantar a questão: por que Deus não os cercou pelos quatro lados? Por que deixou um deles descoberto, necessitado da construção de um muro para completar Seu desejo de aprisionamento daqueles povos? A resposta, parece-me, liga-se ao fato de que esses povos um dia escaparão. E quando isso acontecer não será por falha nos empecilhos criados por Deus, pois perfeitos, mas nos criados pelo homem, portanto falíveis.

Próximo ao muro, mas do lado de fora, há outra legenda, que diz:

Isti inclusi idem esse creduntur . qui a solino antropophagi [em vermelho] dicuntur inter quos et essedones [em vermelho] numerantur nam t pre [tempore] anticristi erupturi et omni mundo persecucionem illaturi [Esses enclausurados, também se acredita, são os que Solino chamou de Antropófagos, entre os quais os Essedones ${ }^{22}$ devem ser listados. De fato, no tempo em que o Anticristo aparecer, por todo o mundo se espalharão perseguições].

Apenas essa legenda informa da conexão entre os filhos de Caim e o Anticristo, assim como do papel que desempenharão quando fora de seu encerramento. Porém, o mais interessante nessa legenda é que o cartógrafo de Hereford procurou estabelecer uma tipologia. Há outros povos antropófagos, os aprisionados atrás da muralha não são os únicos. Mas a que serviria essa tipologia? De certo modo, ela diminui a aberração representada pelos povos de Gog e Magog? Acreditamos que essa tipologia liga-se ao caráter unidimensional com que as gentes são apresentadas, isto é, apenas uma característica do povo deve ser destacada. Os filhos de Caim são os servidores do Anticristo e representam todo o horror imaginável. Essa característica não deve se contaminar com outras. Sua antropofagia faz parte dos horrores que representam, não é sua característica distintiva. Para os Essedones, a antropofagia é sua característica distintiva. Ricardo de Hal-

21 As semelhanças entre a legenda em Hereford e a descrição na Cosmographia são ressaltadas por S. D. The Hereford map. Op. cit., p. 68. Note-se que há uma grande semelhança entre o texto do mapa e o equivalente na Expositio Mappe Mundi, mas este último também deve ter-se baseado em Aethicus Ister.

22 No mapa, em outra localidade, há uma figura específica para os Essedones, retratados em seu canibalismo. 
dingham quis deixar bem claro que esses povos, apesar de compartilharem um elemento "cultural", não podiam ser comparados, pois eram diferentes em seu fator identitário preponderante, necessariamente único.

Mas a muralha não é a única referência aos povos de Gog e Magog do mapa. No extremo Norte, próximo à terra dos Hiperbóreos ${ }^{23} \mathrm{e}$ aos altares de Alexandre que marcam o limite norte de seus domínios, está uma ilha chamada de Terraconta. A ilha mais próxima desta é chamada de Insula Mirabilis, e sua legenda diz quam Alexander non nisi per pces et obsides intuit [a qual Alexandre não visitou sem preces e garantias]. Novamente o macedônio vincula-se aos filhos de Caim.

Figura 2. Terraconta - Mapa de Hereford.

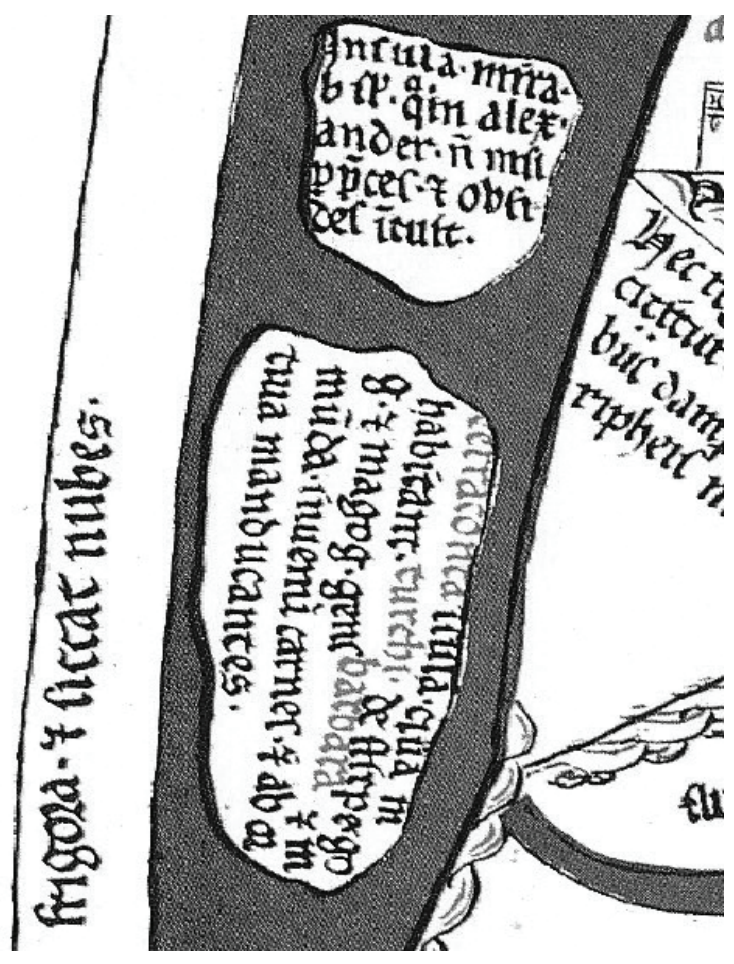

Na ilha Terraconta (Figura 2, a ilha maior, à esquerda), onde não há iconografias, apenas o texto de sua legenda, lê-se Terraconta isula . qua inhabitant . turchi

23 Povo que vive mais ao Norte - hiperbóreos. Segundo Solino, vivem em constante discórdia, quando alcançam certa idade, jogam-se no mar de um alto penhasco. Não há figura que os acompanhe, apenas as montanhas que limitam o território em que vivem. 
de stirpe gog et magog. gens barbara et inmuda. iuuenũ carnes et arbortiva munducantes [Ilha de Terraconta, na qual habitam os turchi, da estirpe de Gog e Magog. Uma raça bárbara e imunda, que se alimenta da carne de jovens e abortos].

Os "filhos malditos de Caim" não foram explicitamente chamados de povos de Gog e Magog, mas esses turchi são apresentados como de sua estirpe. Encontram-se em uma ilha, portanto enclausurados, e apresentam hábitos tão terríveis quanto os primeiros. São eles uma segunda apresentação dos mesmos povos? Naomi Kline acredita que sim. ${ }^{24}$ Todavia, a legenda diz que são "da estirpe de Gog e Magog" (grifo meu). Pertencem, portanto, à mesma linhagem - mas são o mesmo gens, ou o mesmo povo? Acredito que não nesses termos. Esses outros filhos de Caim, afinal da mesma estirpe, possuem um gentílico próprio - turchi -, são outro povo. Podem ser vistos como outro ramo da mesma gens, mas não são idênticos aos aprisionados por Alexandre. Como um ramo de uma grande gens, compartilham algumas das características do tronco principal, pois o ancestral da "raça" é o determinante de seu caráter, mas ramos secundários não compartilham do mesmo destino ou glória (para o bem e para o mal) do eixo central.

Desempenhariam algum papel no drama do Juízo? As legendas não tratam disso. Porém, a semelhança entre "turchi" e "turcos" é notável. Mas o que é um "turco" no século XIII? A Cosmographia de Aethicus Ister, de meados do século VII, já estabelecia uma relação entre o nome Turchi e os povos de Gog e Magog. ${ }^{25}$ Provavelmente, essa palavra era um gentílico geral para bárbaros, não definidos apenas pela língua que falavam (ou não falavam), mas já agregada à conotação de violência e selvageria. A fonte da legenda no mapa é a Expositio Mappe Mundi, que apresenta virtualmente o mesmo texto. ${ }^{26}$ Por sua vez, a Expositio deve ter-se baseado na Cosmographia. ${ }^{27}$

Entre os seis termos usados por Aethicus Ister para caracterizar os turchi como uma gens desprezível não consta a palavra "bárbaros". Na legenda de Hereford, essa palavra está em vermelho. Por quê? Bárbaro é um adjetivo pejorativo referente ao comportamento dos turchi que merece destaque? Essa palavra apa-

24 KLINE, Naomi R. Op. cit., p. 184-185.

25 Cf. KLINE, Naomi R. Op cit., p. 186, n. 61. Portanto, muito antes de os povos hoje chamados de turcos alcançarem as fronteiras europeias.

26 Entre a informação da Expositio e o mapa, a diferença é que este não apresenta as duas últimas palavras constantes na Expositio.

27 Cf. WESTREM, S. D. Op. cit., p. 136. 
rece mais uma vez no mapa, novamente em uma referência etnográfica sem iconografias. No Sul da África, próximo ao território habitado por diversos portentos, há uma pequena inscrição, sem iconografia, que diz Hic barbari . getuli . natabres et garamentes . habitant [Aqui habitam os bárbaros Gétulos, Natabres e Garamantes]. A palavra bárbaro reflete uma tipologia, assim como antropófago. Os turchi eram, pois, bárbaros, isto é, selvagens, e sua selvageria ligava-se a sua ascendência e à maldade que dela provinha.

No século XIII, o gentílico turchi deve ter-se facilmente ligado ao ambiente do final das Cruzadas. O mapa não trata de seu presente, tanto que esses turchi estão no Norte, e não no Leste, mas seu nome certamente ecoava sentidos bem contemporâneos - apesar de acreditar que essa não era a intenção do cartógrafo.

A cidade de Hereford, no século XIII, era uma comunidade relativamente acostumada com a presença do Outro, pois lá se encontrava a segunda maior comunidade judaica da Inglaterra. ${ }^{28}$ Aquele século, porém, foi marcado pela rejeição dessa convivência próxima. Naquele momento, as alteridades mais visíveis aos medievais eram os muçulmanos, contra quem se realizavam as Cruzadas orientais na Terra Santa e ocidentais na Península Ibérica, e os judeus, que desde o século XI passaram a sofrer perseguições cada vez maiores e mais violentas. ${ }^{29}$ A comunidade de Hereford deve ter sido atingida muito proximamente por essa rejeição, e seu mapa a registra. Primeiramente, por uma grande rejeição ao presente. Os "Outros" representados em Hereford não guardam relação direta com os acontecimentos do século, mas vêm dos livros e das tradições mais antigas. A rejeição à alteridade é tamanha que em Hereford os Outros só aparecem perifericamente, mal se diferenciando dos portentos. De certo modo, a verdadeira alteridade era formada pelos portentos, pois os Outros que não possuíam partes de seu corpo fora da "normalidade" eram um mero apêndice daqueles. O diferente era antes e acima de tudo estranho.

A permanência de um olhar dicotômico sobre a realidade, que a dividia em pares de oposição, era um elemento central da perspectiva medieval da alteridade. A distinção Mesmo/Outro se relacionava com a mais básica entre bem e

28 FLETCHER-JONES, Pamela. The Jews of Britain. Oxford: Windrush Press, 1990. Destaque-se que os judeus foram expulsos da Inglaterra no final do século XIII.

29 MALKIEL, David. Jewish-Christian relations in Europe, 840-1096. Journal of Medieval History, v. 29, n. 1, mar. 2003. Ligadas aos ideais de purificação do mundo expressos com grande violência nas Cruzadas. 
mal, Deus e o Diabo. O questionamento da humanidade do Outro não se articulava em um questionamento da semelhança de figura entre esses e os ocidentais, mas se relacionava com a retirada de sua dignidade humana, só conferida pela profissão da fé segundo a ortodoxia cristã. O caso de Gog e Magog e dos turchi é um exemplo extremado dessa perspectiva, mas que funcionava como padrão de referência para a quase desumanidade do Outro.

\section{O Mesmo e o não Mesmo}

O principal elemento a unir as diferentes sociedades do medievo ocidental era o cristianismo. É nele, portanto, que se encontra o principal elemento aglutinador da percepção medieval da alteridade. Os medievais estavam acostumados a pensar o mundo em pares de oposição, em que o conjunto Céu/Inferno, ou Deus/ Diabo, fornecia o paradigma. O mundo dos homens dividia-se entre aqueles que conheciam o Cristo e tinham um estilo de vida correto marcado pela fé e aqueles que não o tinham. Assim, a alteridade, de fato, é unidimensional. Representa apenas o não Mesmo. O cristianismo possui um projeto totalizador, não apenas porque se imiscui em todos os aspectos da vida do crente, mas porque defende a pregação e a conversão de todo o gentio. O não cristão (ou o não Mesmo) é um, digamos, cristão em potencial, pois sua existência só faz sentido como um ainda não converso, ou um pecador inveterado. Boa parte das representações da alteridade em Hereford, e especificamente os povos de Gog e Magog, pode ser percebida como de pecadores.

Uma comparação interessante e bastante esclarecedora da noção de Outro posta em Hereford pode ser feita considerando-se duas pequenas histórias de judeus presentes na Legenda áurea. Nesse contexto, e em diversos sentidos, a alteridade mais próxima aos cristãos medievais era formada pelos judeus. Essa proximidade milenar, se não forneceu o modelo de relação medieval com o Outro, ao menos nos permite estabelecer um paralelo de suas características com grande clareza.

Na Legenda áurea, de Jacopo de Varazze, há diversas histórias em que aparecem judeus, mas virtualmente todas seguem um mesmo padrão. No conjunto de narrativas referentes a São Nicolau, há duas historietas em que eles desempenham papel importante, e o padrão pode ser verificado. Na primeira, um cristão havia tomado certa quantia emprestada a um judeu, mas, não tendo como 
fornecer garantias ao empréstimo, jurou sobre um altar de São Nicolau que lhe devolveria o dinheiro assim que pudesse. O tempo passou e, como o empréstimo não foi pago, o devedor foi levado a juízo. Para não pagar o débito e mesmo assim evitar ser punido, o cristão elaborou um plano. Seguiu para o tribunal com uma bengala oca, recheada com moedas de ouro. Quando foi prestar juramento, pediu ao judeu que lhe fizesse o favor de segurar sua bengala, e jurou ter restituído até mais do que o que havia pedido. Depois do juramento, pediu a bengala de volta. Dessa maneira, pretendia safar-se do pagamento da dívida, pois de certo modo a havia pago, e o judeu, de bom grado, lhe devolveu o dinheiro. Saindo do tribunal, sentiu um sono repentino e dormiu em um cruzamento, sendo atropelado por uma carroça, que o matou e destruiu a bengala, revelando sua artimanha. $\mathrm{O}$ judeu, porém, recusou-se a pegar o dinheiro que era seu por direito, afirmando que só o faria se o morto ressuscitasse pelos méritos de São Nicolau - o que aconteceu quase imediatamente, levando o judeu a se converter e a se fazer batizar.

A segunda história, narrada logo em seguida à anterior, diz que um judeu, testemunha do poder miraculoso de São Nicolau, mandou fazer uma imagem do santo e a colocou em sua casa. Quando empreendeu uma longa viagem, disse à imagem: "Nicolau, aqui estão todos os meus bens, que confio a você; se não fizer boa guarda, vingo-me com chicotadas." Apesar disso, sua casa foi roubada, sendo deixada para trás apenas a imagem de Nicolau. Ao ver-se sem seus bens, o judeu cumpriu o prometido e puniu a imagem por não ter protegido adequadamente sua propriedade. Quase imediatamente, São Nicolau apareceu diante dos ladrões, todo ensanguentado, exigindo que devolvessem os bens furtados, ou seriam punidos. Assustados, os ladrões cumpriram a ordem e contaram o milagre. Por sua causa, o judeu se converteu e abraçou a fé cristã. ${ }^{30}$

Por essas histórias percebe-se que o olhar medieval sobre a alteridade a reduzia ao Mesmo. Os judeus, ao menos os dessas anedotas, apesar de não serem cristãos, reconheciam o valor de um juramento sobre um altar e mandavam esculpir imagens de santos. Ao fim das histórias, ambos abandonaram sua fé e converteram-se ao cristianismo. Era como se a alteridade existisse apenas para se converter e dar testemunho do poder divino. E, mesmo em sua existência pré-

30 As duas histórias estão no terceiro capítulo do primeiro livro da Legenda áurea, aqui consultada na tradução de FRANCO JR., Hilário. Legenda áurea: vidas de santos. São Paulo: Cia. das Letras, 2003. p. 74-75. 
-conversão, adotavam alguns hábitos cristãos. O mapa de Hereford informa que os hircani habitam perto do rio Oxus, e os habitantes das ilhas Eones vivem das aves marinhas, porém, no mais, permite inferir que viviam como o Mesmo.

Há uma única representação de judeus no mapa de Hereford, mas não no conjunto iconográfico das alteridades e, sim, nas representações da história. Os Iudei foram postos na base do monte Sinai, adorando o bezerro de ouro, enquanto Moisés em seu topo recebia as Tábuas da Lei. Importante na representação do Outro era mostrar seu erro, e não suas semelhanças. Se em narrações como as da Legenda áurea a alteridade era apresentada em etapas (1. repetindo o erro; 2. no momento da revelação; 3. na conversão final), as figuras postas em Hereford pretenderam-se mais eloquentes e diretas na marcação exclusiva da diferença, pois, diferentemente da obra de Varazze, não sustentavam uma narrativa, mas serviam de mote para as prédicas.

Todas as figuras de alteridade apresentam-se distantes dos pontos mais significativos do mapa e mostram-se unidimensionalmente. Os "outros" povos ou são guerreiros, ou medrosos, têm bons hábitos ou comportam-se de maneira mais selvagem que a pior besta - não há meio-termo, não há complexidade. Essa representação, que se submetia a uma oposição binária primordial, ser ou não cristão, sobrepunha-se ao antagonismo humano/não humano. Esta última sobreposição não era simples e direta, mas guardava grande ambiguidade e era marcada por uma tensão básica: seriam as outras gentes verdadeiramente humanas?

Os medievais não apresentavam a questão nesses termos. Elucubrações sobre sua humanidade em termos raciais não faziam parte do repertório medieval, mas a certeza do paganismo do Outro lhe retirava qualquer dignidade humana. Os "malditos filhos de Caim" que comiam carne humana claramente não eram pessoas como os frequentadores da catedral de Hereford.

A ignorância geral sobre o estilo de vida do Outro engendrava a consolidação de uma percepção unidimensional e antitética deste, que em muito contribuía para sua desumanização. Apesar de suas formas humanas, os outros povos podiam mostrar (monstrare) sentidos secundários, servir como alertas, sinais de desígnios divinos - do mesmo modo que os monstros e portentos. Afinal, todo o Cosmos era como um livro para a escrita divina.

A representação dos portentos e monstruosidades era, em grande parte, um olhar sobre o Outro. Era uma maneira de apreender e lidar com a existência de 
povos fora dos limites da cristandade. A peculiaridade medieval é que entre o mundo que entendemos por natural e o que definimos como humano havia uma fronteira muito flexível em alguns de seus aspectos. Humanos e animais compartilhavam características e muitas vezes podiam confundir-se, como o bezerro nascido de uma mulher registrado por Isidoro de Sevilha, ${ }^{31}$ ou os cinocéfalos, uma gens com cabeça de cachorro, ou ainda os simeae, criaturas tão semelhantes a homens que era fácil confundir uns com os outros - daí o termo "símios".

Agostinho acreditava que os cinocéfalos obviamente não eram humanos, apenas simeae. O bispo de Hipona define a humanidade em poucas palavras, considerando como homens apenas as criaturas descendentes de Adão. Mas as outras criaturas de Deus não eram nosso oposto - não era em relação a elas que o Humano se definia.

Não havia unidade entre humanos e animais, é claro, mas todas as criaturas vivas compartilhavam de certa contiguidade no espaço ideal que ocupavam na mente dos medievais. Os portentos demonstram que pode ser inútil procurar uma fronteira clara entre os animais e os humanos em suas formas ou em suas vidas terrenas. Deve-se, pois, optar pela percepção de um continuum e de uma grande imbricação. É como se existisse um polo humano, mas não um polo completamente inumano e seu oposto, pois o olhar medieval sobre o Cosmos projetava neste uma vontade e um funcionamento que tinha o homem como padrão. ${ }^{32}$

31 SEVILHA, Isidoro de. Etimologias. livro XI, cap. 3. Disponível em: <http://www.thelatinlibrary. com/isidore.html>. Acesso em: 23 jan. 2012.

32 GUREVICH, Aaron. Categories of medieval culture. Londres/Boston: Routledge \& Kegan Paul, 1985, em especial sugere-se ver o capítulo intitulado “The Divine Comedy before Dante”. A teoria do micro/macrocosmo, ou seja, a concepção de que o corpo do homem é análogo ao Cosmos, era defendida por diversos pensadores medievais e reproduzia as percepções populares do período. Gervásio de Tilbury, cujos escritos foram a base para um outro famoso mapa-múndi medieval - Ebstorf -, defendia essa leitura, afirmando na primeira parte das Otia Imperialia: "em suma, o homem deve se chamar mundo [...] os gregos chamavam o homem de microcosmo, que significa mundo menor [...] mundo, este é o homem" (In summa homo mundus appellatur [...] et graecus hominem microcosmus hoc est minorem mundum appelabat [...] et mundus, hoc est homo). Apud WOLF, A. News on the Ebstorf map. In: PELLETIER, Monique (Org.). Géographie du monde au Moyen Age et à la Renaissance. Paris: Éditions du Comité des Travaux Historiques et Scientifiques, 1989. Essa percepção era quase natural em um sistema de pensamento que entende o universo criado a partir da expressão da vontade de uma única divindade que coroa sua Criação com uma criatura ad imagine Sua. Assim, todo o Cosmos se define em um jogo de imagens em que um original (imaterial) reflete-se em todas as imagens (materiais). 
Aristóteles, e com ele toda a escolástica, acreditava que a alma compreende três elementos, a alma nutritiva, compartilhada por homens e plantas, a alma sensivel, compartilhada por homens e animais, e a alma intelectiva, exclusiva dos homens. ${ }^{33}$ Essa sutileza universitária não devia alcançar plenamente o saber popular, mas a diferença entre humanos e animais certamente era percebida pelos medievais como a posse de uma anima, um vigor - uma coisa - a mais que os outros seres, por menos letrados que fossem..$^{34}$ Mas estabelecer a distância ente o mundo humano e o não humano não parece ter sido uma grande preocupação dos medievais. Essa foi uma questão moderna. ${ }^{35}$

Keith Thomas sugere que, na Inglaterra do início da Modernidade, era usual considerar o mundo como feito para o homem. ${ }^{36}$ Essa era a herança medieval. O Cosmos fora criado para satisfazer nossas necessidades. Sua própria existência era dependente da nossa, não o contrário. Porém, não é necessário esperar os tempos modernos para que essa percepção inicie seu processo de mudança. Os últimos tempos medievais, em especial depois da redescoberta de Aristóteles, foram marcados pela imagem de uma natureza que se submetia a leis - leis divinas que a faziam submissa ao homem, mas leis. O que chamamos de natureza começava a ganhar autonomia em relação aos desejos e necessidades humanas. Mas o século XIII não viu esse processo concluído - talvez nem nosso século o veja. Os anos 1200 refletem na arte um olhar sobre o mundo natural que se expressa tenso, ambivalente, entre ler o mundo como um largo conjunto de metáforas e lê-lo como um conjunto coerente de criaturas que se inter-relacionam - por mais fantásticas que sejam. ${ }^{37}$ No mapa de Hereford, o Cosmos apresenta-se em toda a sua

33 Cf. THOMAS, Keith. O homem e o mundo natural. São Paulo: Cia. das Letras, 1988. p. 37.

34 Esse sistema de pensamento não era fechado sobre si mesmo, tendo incorporado diversos acréscimos das mais diversas origens. Mas esses acréscimos inseriam-se em um sistema de pensamento cuja amarra era o cristianismo e cujos intelectuais mais significativos expressavam-se sob sua égide.

35 Cf. THOMAS, Keith. Op. cit.

36 Id., p. 61.

37 Essa tensão é particularmente perceptível no gótico. Há, porém, trabalhos clássicos, como o de Wilhelm Worringer (Form in gothic. Tradução inglesa de Formalprobleme der Gothik. Londres: A. Tiranti, 1957), que tendem a ler esse estilo reforçando seu lado simbólico e a força de seu misticismo. O tamanho, o formato das torres, as tramas das ogivas, a aparente leveza de conjuntos tão pesados, o sentido das linhas levando ao alto, o valor e uso da luz, enfim, todas as características significativas do estilo ressaltariam sua espiritualidade. Por outro lado, o naturalismo das representações de pessoas, plantas e animais permitiria defender o oposto. Os séculos do gótico, pois, podem ser lidos como um período em que duas percepções diferentes concorriam, sem uma competição 
exuberância e cada coisa tem seu lugar, mas Deus (Cristo entronizado) ainda rege o mundo, do alto, e a partir da teleológica perspectiva da Salvação.

Os homens se submetem à vontade divina, tendo seus destinos marcados por sua origem - o ancestral que fornece o caráter - e pelos desígnios de Deus como se pode ver na expressão "Malditos Filhos de Caim". Esses seres carregam a ambiguidade de serem humanos, mas condenados. E, condenados, possuírem hábitos desprezíveis, selvagens.

$\mathrm{O}$ que de certo modo surpreende em Hereford, tão rico em representações pictóricas, é a relativamente pequena quantidade de representações iconográficas desse tipo de alteridade - etnográfica. Há apenas 11 registros do Outro. Certamente porque, para seu produtor e público, a separação entre portentos e povos distantes não existia, ou, de tão tênue, era como o papel de seda que recobre as figuras em um livro antigo. Traçar uma fronteira entre as duas representações como se estas refletissem duas percepções diferenciadas é mais uma necessidade moderna de categorização, e subcategorização, que uma determinação do olhar medieval. Os hábitos hediondos refletiam-se, em muitos povos, em sua aparência hedionda.

Esse olhar percebia as categorias com que se instrumentalizava para enxergar a realidade de uma maneira menos estanque e compartimentada que o nosso. A interpenetração, ou a continuidade das categorias, é uma forte característica da percepção medieval, mas não pode ser entendida como um tipo de falha. Longe de gerar confusões ou ser reflexo de um primitivismo (ou pensamento pré-lógico) daquela mentalidade, a contiguidade das categorias reflete o impacto da vivência medieval do cristianismo sobre suas concepções de mundo. Antes de tudo, o Cosmos era a ordenação de uma única e soberana vontade divina. Assim, todas as suas partes eram, na verdade, reflexos desta. Variações do mesmo tema, como em um exercício retórico de repetição para obter o efeito desejado.

Lévi-Strauss, em um de seus livros clássicos, ${ }^{38}$ busca demonstrar que o pensamento dos selvagens não deveria ser definido como infantil, ou pouco afetado pela experiência civilizacional. O "primitivo" não era um ser recém-lançado na natureza que se apropriava dela com a inocência de crianças de pureza idealizada.

direta ou acirrada entre ambas, com(o) reflexos (d)nas inovações técnicas. Não é desprovido de significado que nesses mesmos séculos desenvolvia-se a escolástica aristotélica e o misticismo.

38 LÉVI-STRAUSS, Claude. O pensamento selvagem. Campinas: Papirus, 2006. 
Seu olhar sobre o mundo era resultado de um processo de reflexão e de um exercício especulativo que o autor considera "próximo daquele dos naturalistas e herméticos da Antiguidade e da Idade Média: Galeno; Plínio; Hermes Trimegisto; Alberto, o Grande...." ${ }^{39}$ Ou seja, a classificação dos medievais (ou dos ditos selvagens) não poderia ser considerada menos o resultado de uma empreitada racional que de uma intuição frágil e infantil. Seus sistemas de classificação apenas se submetiam a lógicas próprias e originais, mas nem por isso atrasadas em relação a uma razão perfeita e/ou mais evoluída e bem-acabada - pretensiosamente, a lógica ocidental moderna. Toda a simbologia do pensamento medieval pode ser entendida a partir de seu peculiar sistema de classificação e das relações que se construíam entre seus entes - como, por exemplo, entre os animais e as virtudes e/ou pecados.

O mapa de Hereford é um grandioso produto dessa lógica e nos fornece chaves para compreendê-la, pois ressalta a contiguidade entre os entes do universo e os põe em seus lugares. Da mesma maneira que os homens do período tendiam a olhar o espaço como uma contiguidade, em que se inseriam diferentes níveis de qualidade/sacralidade (do Éden ao Inferno), lado a lado apresenta seres de diferentes níveis de humanização, mas que nem por isso deixam de ser algo humanos.

As 11 representações mais claramente humanas ocupam, no continuum em que se inserem, um lugar mais próximo do polo plenamente humano - descendentes de Adão e Eva, que possuem alma e podem ser alcançados pela Boa-Nova.

A sociedade do Ocidente medieval caracterizou-se, por muito tempo, por seu isolamento. Depois da queda do Império Romano do Ocidente, do distanciamento entre a parte latina e a grega da civilização mediterrânea e do avanço árabe que empurrou o Ocidente mais para o Norte, os medievais passaram a ocupar uma periferia do mundo. Cada vez mais voltado para si mesmo, o Ocidente desaprendeu a conviver com o diferente - o que foi reforçado pelo caráter excludente de uma religião de salvação baseada no culto de um Deus único e exclusivo. ${ }^{40} \mathrm{O}$ "Outro" era, portanto, uma realidade distante e negada pelo cotidiano. Existia em um além geográfico que, se, por um lado, ajudava a definir as fronteiras da

39 Id., p. 58.

40 Destaque-se que me refiro ao "Outro" no sentido civilizacional. A cristandade, mesmo com sua diversidade interna, forjou na Europa uma civilização cujos pressupostos básicos eram compartilhados por seus integrantes. 
cristandade, por outro, podia ser definido como um difuso "não-é-o-Mesmo"/ não-é-cristão.

A geografia foi um fator fundamental para a constituição do Outro. Não tanto a geografia "real", mas uma geografia mental que separava as comunidades. ${ }^{41}$

Na verdade a geografia não tinha lugar no catálogo medieval das sete artes liberais e por isso, sem a dignidade de uma verdadeira disciplina, ela torna-se repositório de conhecimentos e pseudoconhecimentos, de dogma bíblico, de histórias de viajantes, de especulações de filósofos e do imaginário mítico. ${ }^{42}$

As descrições do espaço além-cristandade e de seus povos no mapa de Hereford inseriam-se no projeto civilizacional eclesiástico e em um repertório organizado em uma sociedade extremamente dependente da oralidade. O conjunto de conhecimentos clássicos, ou consagrados pela tradição, à disposição de Ricardo de Haldingham deu forma às representações da alteridade, tanto quanto o desejo catequético presente nas obras realizadas por, ou consagradas a, clérigos.

Quando Gregório Magno sugeriu o uso das imagens para possibilitar uma "leitura" das verdades da fé pelos iletrados, não se pretendia que o contato com as imagens fosse apenas um momento pacífico e/ou de reflexão. Diferentemente do processo de juntar letras e ecoar palavras e significados na mente, olhar imagens implica um contato mais completo com seus significados. A velocidade com que este atinge os sentidos e a característica devocional das imagens fazia com que essa "leitura" fosse muito mais que a relação entre significantes e significados. "Ler" as imagens implicava uma aproximação física com os significados sagrados. A atividade mais intelectualizada da leitura dava lugar, no exercício de olhar imagens, às mais diretas e materiais manifestações de adoração. ${ }^{43} \mathrm{O}$ caráter

41 Assim, comunidades judaicas dentro dos territórios da cristandade ocupavam um espaço muito distante na geografia mental. Como o mapa não retrata judeus como alteridade, estes não entraram na análise, servindo, em poucos momentos, apenas como referência de controle e comparação.

42 BOORSTIN, J. Os descobridores. Gradiva: Lisboa, 1994. p. 103. O autor acaba por reproduzir preconceitos que lembram a lenda de uma Idade de Trevas, mas, apesar de discordar de suas concepções básicas, é necessário reconhecer que o conhecimento espacial medieval era uma colagem de elementos de diversas fontes. Todavia, não se pode considerar que essa colagem fosse resultado de a geografia não ser uma "verdadeira disciplina" - o que quer que isso signifique. Boorstin não utiliza nenhuma das contribuições da antropologia cultural, que talvez lhe permitissem perceber que cada cultura organiza o conhecimento a partir de suas próprias categorias de pensamento.

43 BROWN, Peter. Images as a substitute for writing. In: CHRYSOS, Evangelos; WOOD, Ian (Eds.). East and West: modes of communication (proceedings of the First Plenary Conference at Mérida). 
didático das imagens não se dava apenas pela intelecção de seus significados, mas pela experiência que esse contato possibilitava. As figuras em Hereford, mesmo as não devocionais, compartilhavam da força desse contato. No que se refere à alteridade, certamente não há espaço para a adoração, mas a reação que deveriam provocar tinha o mesmo grau de impacto. Se o Outro é rejeitado, suas figuras devem provocar rejeição. Se o Outro é diferente e grotesco, assim suas figuras manifestam-se.

Apesar de pretender-se um inventário da Criação, o mapa de Hereford jamais poderia ser completo. Devia optar, pois, por expressar o mundo mais do que descrevê-lo em mínimos detalhes. As representações do Outro refletem seu sentido - sua selvageria e o caráter hediondo de suas vidas. Assim, a diversidade de povos pode ser reduzida; afinal, são todos iguais na única característica que importa - não são o Mesmo.

Já em Orósio, vê-se uma pequena diversidade de gentes. Em sua descrição da geografia do mundo, a cada região apontada, trata de um mínimo de 28 (Mesopotâmia) a um máximo de 44 (Índia) nações. ${ }^{44} \mathrm{~A}$ humanidade é diversa, mas de uma diversidade relativamente limitada. Porém, Orósio ainda era um escritor da Antiguidade. Seu período ainda tinha não só a lembrança, mas a experiência de um Imperium universal e multicultural. Para os medievais, todavia, o mundo era muito menor ou muito menos diverso. As variações da humanidade espelhavam a única relação de alteridade possível, ser ou não cristão, e, dentro desta, estar ou não na heresia. Uma sociedade com tanta ideia de limite como a medieval - o próprio universo é limitado por uma casca - não pode conceber uma variedade infinita de modos de vida. Na verdade, há apenas um modo de vida possível; os outros são deturpações, deteriorações, aberrações. Mesmo não se constituindo em portento, o Outro sempre será uma coisa portentosa, por seus hábitos.

Em Hereford, o Outro é expresso como em um show de horrores. Quem o vê maravilha-se com o espetáculo, teme a diferença e regozija-se por estar "salvo". Todo homem é culpado pelo Pecado Original, apenas o arrependimento

Leiden (Holanda): Brill Academic Publishers, 1999. p. 15-34, mais especificamente p. 23-25. 44 ORÓSIO, Paulo. Historias. Introdução, tradução e notas Eustáquio Sánchez Salor. Madri: Gredos, 1982. livro 1, cap. 2. 
e o batismo na Ecclesia podem redimir essa situação. Estar na Comunidade ${ }^{45}$ dos integrantes da Igreja, dos seguidores da fides em Cristo, é a única maneira de abandonar a essência fraca e pecaminosa da humanidade. Quem estava fora da Ecclesia era um ser humano de segunda categoria. A Bíblia, em especial o Antigo Testamento, reforçava esse padrão de relacionamento com o Outro: só há um povo escolhido, agora, os cristãos; os demais, do que uma humanidade limitada, têm uma alma limitada.

O olhar medieval sobre o mundo é egocêntrico - o mundo existe por causa do homem, o homem de primeira classe, o cristão, único com a chave para decodificá-lo. Uma vez que as outras gentes existiam como um veículo para os desígnios de Deus, e Sua vontade é única, sua leitura metafórica também só podia ser única/unidimensional.

Em sociedades fortemente influenciadas por meios orais de transmissão de conhecimento, a elaboração de um discurso depende das características da oralidade. Na transmissão de saga, por exemplo, cada herói é lembrado por uma de suas características distintivas. Do mesmo modo, os outros tipos de informação têm de se vincular a um elemento distintivo que os tornem facilmente acessíveis à mente. Para guardar imagens do Outro, era necessário, pois, eleger um elemento distintivo que facilitasse seu armazenamento na memória. Hereford registra a lembrança da alteridade dentro de categorias possíveis aos medievais e reforça essas mesmas categorias ao se fiar sempre em um elemento distintivo. Os povos de Gog e Magog são um exemplo extremo, mas paradigmático, da percepção mais geral da alteridade que, dentro de três eixos de relação com o Outro, axiologicamente Hereford opta por definir como "o mau"; praxiologicamente, por rejeitar tudo o que oferecem, e, epistemicamente, por ignorar.

45 Nunca é demais lembrar que Ecclesia pode-se traduzir como comunidade, assim como por assembleia, e origina nossa palavra igreja. 